\title{
Political Aspects of Reproduction of Inequalities in the Republic of South Africa*
}

\section{Polityczne aspekty procesu reprodukcji nierówności w Republice Południowej Afryki}

\section{- Abstrakt •}

RPA zostało w ostatnich latach uznane za „najbardziej nierówne pod względem dystrybucji bogactwa i dochodów” państwo świata. Współczynnik Giniego dla dystrybucji bogactwa wynosi tam $0,96 \%$, co idealnie odzwierciedla nierówności w skali całego globu. Celem artykułu jest odpowiedź na pytanie, w jaki sposób nierówności odziedziczone z okresu apartheidu były pogłębiane po 1994 roku.

Słowa kluczowe: RPA; nierówności

\section{- Abstract •}

The Republic of South Africa has been recently recognized as the world's "most unequal state in terms of wealth and income distribution". The Gini coefficient for wealth distribution in South Africa stands at $0.96 \%$, which perfectly reflects the total coefficient of wealth distribution across the globe. The purpose of the article is to answer the question of how inequalities inherited from the apartheid period were even further aggravated after 1994.

Keywords: Republic of South Africa; inequalities

* The present paper is a deliverable of the research project of the National Science Center: Strategies for equal opportunities in post-apartheid countries - a comparative analysis, UMO-2017/25/B/ /HS5/00929 (orig. in Polish: Strategie wyrównywania szans w państwach post-apartheidowych. Analiza porównawcza). 


\section{Introduction}

\section{Objectives of the Paper}

Questions resonating at South African universities in 2018 and 2019 (especially after the 'fee must fall' campaign, a wave of student protests against increases in tuition fees and xenophobic attacks on foreigners) focused on whether South African democracy could survive in the current conditions of inequality. What model of redistribution of goods would work best in South African environment? Is South Africa following the path of other sub-Saharan states, where after decolonization a strengthening of clientelism and neo-patrimonial systems could be frequently observed? Is this the "natural" course of development in postcolonial African countries (as the fall of apartheid is often presented as the last chord of the decolonization process)? This all contrasted strongly with the fact that the Republic of South Africa is a country where redistributive policy is, declaratively, the government's priority program. Many South African academics argue that South Africa is redistributing the largest percentage of the budget among the developing country group (over 3\% of GDP [!] is being redistributed by the state through various "social grants"). One cannot argue with the fact that the so-called social grants are one of the most important budget items for the Republic of South Africa, but neither the grants nor actions aimed at increasing the share of black people in the state economy (so-called Black Economic Empowerment programme) have contributed to the reduction of inequalities. Moreover, the unsucessful land reform became the main target of political attacks of the populist Economic Freedom Fighters party - which claims that a transfer of agricultural land belonging to white farmers into the hands of black South Africans would be a panacea eliminating social inequalities (Polus \& Cześnik, 2016).

The main purpose of research that served as the foundation for the paper was to understand what processes made the attempts at decreasing inequalities (as concerns both income and wealth distribution) in post-apartheid South Africa so ineffective. This issue is particularly interesting from a cognitive point of view; multidimensional inequalities were the main problem faced by South Africa in 1994 - nowadays, a quarter of a century after the African National Congress (ANC) came to power, the country is even more socially stratified than in the late period of apartheid. 


\section{Research Methodology and Structure of the Paper}

The paper adopts the lenses of social constructivism - at the ontological level, this refers to the assumption that what is named as reality, including the phenomenon of inequality itself, is a social construct. An attempt was made to define the processes of emergence of social structures that strengthened inequalities in South Africa. The author, according to socio-constructivist epistemology, focused more on understanding rather than explaining the phenomenon of social stratification in the Republic of South Africa after 1994. The article follows a mixed chronological and topical structure.

The oeuvre of Pierre Bourdieu, who developed the concept of mechanisms contributing to social inequality, was among the main sources of inspiration while working on the text. Although the title of the article directly refers to the concepts developed by this French sociologist, his work served merely as an inspiration for conceptualization of research into the topic rather than as a rigid framework in which the entirety of the research process was conducted. Bourdieu focused mainly on the formal education system in France and related exclusion mechanisms. The assumption of the existence of various forms of capital (social, economic, cultural) that are interchangeable and knowledge of conditions for these exchanges within the habitus were a useful conceptual framework for understanding how the rich in South Africa became richer, and the poor either did not change their socio-material status or became even poorer.

Despite numerous study visits in South Africa in the period 2007-2017, inequalities had not been the core subject of the author's scholarly work until 2018 (although their manifestations were visible in both the academic environment and everyday life in South Africa). In September and October 2018 and in February 2019, two consecutive study visits were devoted entirely to the study of inequalities in this country ${ }^{1}$. The visits were preceded by analysis of literature on inequalities on a global scale, in sub-Saharan Africa and finally in the Republic of South Africa itself. The main research technique during study visits was partially structured in-depth interview. Over 40 official interviews were conducted with academic staff, representatives of NGOs involved in the fight against poverty and exclusion, businessmen, government employees and former politicians. Furthermore, several dozen unarchived conversations were held with South African residents

1 The latter study visit was made jointly with Dominik Kopiński, PhD hab. - I would like to thank him for invaluable help in conceptualizing the final version of the text; without his commitment, professionalism and passion for discovering contemporary South Africa this paper would not have seen the light of day. 
about their perception of the problem of growing inequalities. Observation was an important research technique as well. While the research process methodology was rooted in grounded theory approach, readers may nonetheless notice after analyzing the language of the paper that also the elite theory has been referenced. Despite the literature review carried out before and during the study visits, no hypothesis to be falsified in the field research state was put forward. The study was exploratory in nature - after interviews and interactions with the South African citizens, triangulation of obtained data followed. The answer to the research question posed initially was formulated on this basis. The categories of "political elite" or "political capital" were used by respondents during interviews (and not imposed by the author as a framework of reference).

During the research work, statistical data on inequalities in South Africa was repeatedly referred to. It is worth noting here that, unlike in other sub-Saharan countries where the poor quality of data does not allow for drawing solid conclusions and for which the expression "Africa's statistical tragedy" was coined (Jerven, 2013), South Africa's statistical databases are incomparably better, more comprehensive and more accessible than in other countries of the region ${ }^{2}$. The South African Statistical Office has even introduced the option of filtering data sets by the category of "poverty and inequality" (Statistics South Africa, n.d.), a function particularly useful seeing the scope of the present paper. Socio-constructivist epistemology does not reject the possibility of using quantitative data - the important thing is, however, that they should be presented in a specific spatial and temporal context. Thus quantitative data in this text are presented as a confirmation or illustration of the processes discussed rather than as a statistical explanation.

The paper is divided into five parts. After presenting the research methodology and theoretical foundations, the second section is devoted to presenting the discourse on global inequalities and the place of South Africa in this discussion. Next follows a summary of the impact and consequences of the racial segregation system as concerns the scale of inequalities in the Republic of South Africa. The most important part of the paper covers political conditions for creating mechanisms that effectively excluded the majority of South Africans from access to benefits generated by the economic development of the state (though admittedly South Africa was in recession in the years 2008-2009, symptoms of recession are also visible in macroeconomic data from 2017). The final part concludes.

2 The main source of data on poverty are the surveys carried out as part of National Income Dynamics Study (NIDS) - the panel study sample covered close to 30000 South Africans. 


\section{Discourse on Inequalities}

Oxfam reports on global inequalities have been published in parallel with the running of the World Economic Forum in Davos for many years now. The main conclusion from reading them is the steadily deepening social stratification on a global scale - the rich get richer extremely quickly (Oxfam calculated that in 2018 total wealth of the richest people in the world increased by $12 \%$ ), while the poor are either unable to improve their material status or their situation is, getting worse (Oxfam, 2019). The fact that Oxfam managed to introduce the issue of increasing inequalities as a deliberations topic in Davos is encouraging. On the other hand, it masks the lack of action on the part of the Forum to reduce this widening "gap" between the poor and the rich. Studies on inequality have also become the permanent element of the academic canon ${ }^{3}$. Even the neoliberal Economist announced in 2016 that we are now dealing with the golden age of inequality studies (The Economist, 2016). As concerns the Cold War period, the dominant approach to inequality in Anglo-Saxon research of the time was introduced in the 1950s by the Nobel Prize winner in Economics, Simon Kuznets. He posited that in industrialized countries where income is rising, inequalities will also deepen in the short term - however, Kuznets maintained that in the medium- and longterm they will be levelled. The experience of the 2010s (specifically the period after the 2008 crisis) seems to falsify Kuznets' thesis. Currently, we are dealing not only with inequalities growing on a global scale, but we can observe the same gap widening in developed countries - especially in the United States. Undoubtedly, a scholar who set an entirely new tone in the debate about inequality is the French economist Thomas Piketty (2015). In addition to demonstrating that gains on capital are many times higher (over the long-term he estimated them at 6-7\% per annum) than gains from any other forms of wealth creation (such as work), he postulated at least one very practical solution to reduce global inequality a wealth tax. Interestingly, his initiative of universal taxation of wealth was discussed even by the forum famous for its attachment to the notion of economic

${ }^{3}$ It is impossible to name all research centers dedicated to study of inequalities; nowadays such centers operate at the best universities in Europe and the United States. The Stanford Center on Poverty and Inequality at Stanford University is one example; this University also has an ongoing publications series on inequality. Routledge Publishing House similarly runs a series of publications covering a comparable scope (https://www.routledge.com/Routledge-Inequality-Studies/ /book-series/RIQS). In Europe, a center of research in inequality operates among others at the University of Amsterdam; in South Africa, the Southern Center for Inequality Studies at the University of Witwatersrand was the first of its kind in Sub-Saharan Africa. 
freedom, namely the International Monetary Fund. This took place mainly in connection with the postulated fight against tax havens that allow the richest to avoid taxation in countries where they earn their money (or rather where the previously accumulated capital "works" for them). Taxation of wealth is obviously not a magic bullet that will make inequalities disappear. What is necessary is redistribution of the national income in such a way that the poorest gain access to social benefits (mainly education and health care) that will, in turn, allow them to operate more effectively in the labor market and, consequently, accumulate capital. This domain is the focus of political economy and conditions for the allocation of budget funds are decided by individual governments. These days targeted allocation and redistribution of national income and provision of public goods by governments seem to be the only viable alternative to allowing the inequalities to grow. Branko Milanovic, who in his scholarly work focuses on global inequalities, noticed that with income increase in Asian countries, the income disparity between individual countries lessened. He also suggests that 50 years into the future, we might be back to the state of affairs form the early $19^{\text {th }}$ century, when the largest share of the global inequalities index was attributable to income disparity between rich and poor Britons, rich and poor Russians, rich and poor Chinese, and not with the higher average income in Western countries than in Asia (Milanovic, 2016, p. 5). Therefore, from the cognitive point of view, the key question is whether inequality researchers should (like Piketty) focus on case studies of selected states and build generalizations on this basis or (after Milanovic) consider inequalities from a global perspective from the start? Undoubtedly, case studies are easier for technical reasons - usually, statistical data sets from a selected country are commensurate and it is relatively easy to assess the effectiveness of state administration activities aimed at lessening social stratification in a single country. Inconsistencies in methodologies and consequently in data points collected across the globe (leaving aside the matter of quality and reliability of statistical data itself) and difficulties in conceptualizing global effects of anti-inequality policies pose huge epistemological and methodological challenges.

Perhaps then researchers in inequality should focus on either the most extreme examples, or on examples representative for a larger number of countries or an entire region, and only then attempt to synthesize the results obtained? While it is difficult to question the legitimacy of choosing case studies through the lens of their specificity/representativeness for particular processes (e.g., countries in the period of political transition, postcolonial countries, developed countries), extrapolating the results obtained in one country onto a region-wide or global conclusion may be controversial. Nevertheless, such rationalization was behind the author's 
choice of South Africa as the subject of research. Countries located in the South African region (the Republic of South Africa, Namibia, and Botswana) are characterized by widest social disparities - both in terms of income levels and wealth. The Republic of South Africa is moreover widely recognized as the country facing deepest inequalities on the planet. In addition, total inequality indices (both for income and wealth) for RSA almost perfectly coincide with total inequality indicators for the entire globe. The poorest $20 \%$ of South African society receives only $2 \%$ of the nation's income, while globally this figure is at $2.5 \%$. In contrast, the Gini income inequality index for the world and South Africa is identical and was at 0.67 in 2014 (Therborn, 2019, p. 32). Interestingly, at the height of apartheid - in 1971 - the Gini coefficient for South Africa was 0.68, which means that in terms of social stratification no change has been observed since then, despite the changed context and a rapid increase in population (from 23.5 million in 1971 to 57 million in 2018). The racial structure of the richest stratum of South African society has also changed, as it is not entirely made up of whites anymore. This change led to claims that race should currently not be considered an appropriate analytical category through which inequalities in South Africa could be explained, and that instead the concept of "class" is more relevant to the current situation (Interview with J. Seekings, 2019). At the same time, there is a general trend in African studies to move away from analyzing development issues from a class perspective. In addition to the influence of international financial powers that are not interested in investing in this region of the world, the emphasis is placed on typically African socio-cultural institutions that are important for capital accumulation (Neubert, 2019). Such institutions can of course also be identified in the Republic of South Africa. During field research interviews, respondents most often pointed to the phenomenon of black tax $x^{4}$ and the notion of "extended family", which limit the possibilities of individual enrichment of black South African residents. From the author's point of view, while these notions may be relevant in selected case studies, the structural factors that have led to a situation where opportunities to improve one's financial standing are reserved for a narrow group of South Africans seem far more important.

Poor whites did appear in South Africa after the collapse of the racial segregation system, but the phenomenon is marginal and most of the poorest people in South Africa still are black. In 2015, more than half (30.4 million people; 55.5\%)

${ }^{4}$ The term black tax describes the expectations directed at black citizens who improved their material status to share their earnings with both close and distant family. The need to support more people (sometimes more than 10) by a given person means that they are unable to accumulate enough capital to build generational wealth. 
of South Africa's population was described as living in poverty; the poverty line was set at USD 83 per person per month. As it turned out, $64.2 \%$ of the people classified as poor were black, $41.3 \%$ coloured, $5.9 \%$ were of Asian origin, and only $1 \%$ were white (Statistics South Africa, 2017). Interestingly, both poor blacks and whites living in poverty during interviews pointed to the structural impossibility of changing their social status. As they reported, securing their basic life needs takes up so much time and energy that they simply cannot afford to think in the medium- to long-term. This situation may correlate with the phenomenon described in the psychology of "poor people making bad decisions". Simply put, it is naïve to expect that a tired, hungry person living in precarity would be able to behave entirely rationally and effectively learn from their mistakes. A poor man cannot afford failure; a poor man does not have the freedom or time to acquire new skills, which often results in apathy. The dominant emotion observable in respondents during the interviews was frustration and the resulting apathy in the sphere of political activity rooted in lack of faith that an individual and their vote can change anything. The consequence of this disinterest is the falling voter turnout in the Republic, which has decreased by nearly 25 percentage points over two decades (Table 1).

Table 1. Voter Turnout in Parliamentary Elections in the Republice of South Africa

\begin{tabular}{|c|c|}
\hline Year & Voter turnout \\
\hline 1994 & $86.90 \%$ \\
\hline 1999 & $89.30 \%$ \\
\hline 2004 & $76.70 \%$ \\
\hline 2009 & $77.48 \%$ \\
\hline 2014 & $73.48 \%$ \\
\hline 2019 & $65.99 \%$ \\
\hline
\end{tabular}

Prepared on the basis of: Electoral Commission of South Africa.

\section{Is Apartheid Responsible for it All?}

Treating people differently because of their race and, consequently, creating privileged conditions of wealth generation for the whites was at the heart of apartheid (Hirsch, 2005, pp. 9-28). Unequal access to capital, education and political power also has other, multidimensional social consequences. In addition to resulting inequalities pervading in society, researchers nowadays discuss the structural nature of poverty and its generational inheritance. Increasingly, the state of public 
health services is subject to criticism, with the looming risk of return of the HIV/ /AIDS epidemic and tuberculosis. A growing set of identified problems includes alcoholism, teenage pregnancies, high crime levels and xenophobic attacks that are becoming increasingly common (Hanoman, 2018, p. 157). Although much of the research focuses on poverty or unemployment, it seems that they are a consequence rather than a cause of social stratification.

Göran Therborn posited that the root cause of inequalities in South Africa is settler colonialism on the current RSA territory - that huge disparity in wealth and access to technology between indigenous inhabitants of South Africa and newcomers from Europe were later institutionalized (Therborn, 2019, pp. 33-35). Philip Nel laid down a similar hypothesis, arguing that the entire region of South Africa (the Republic of South Africa, Zimbabwe, Botswana and Zambia included) was the single area in Africa most penetrated by white settlers, which resulted in the development of institutions that were exclusive in their social and political nature. The functioning of these institutions built on the foundational principle of excluding certain groups from political influence and opportunities for capital accumulation may be part of the answer as to why countries with very wide social disparities dominate in the South African region. Undoubtedly, Therborn and Nel's arguments are deeply constructivist and could be a perfect explanation for the origins of exclusionary mechanisms in South Africa. It is reasonable though to ask whether the quarter of a century that passed since the fall of apartheid should not be enough time for changes in these mechanisms to occur? Are the exclusive social institutions established as a result of settler colonialism and formalized during the apartheid period so deeply rooted in the South African habitus that they do not change and are still able to socialize individuals and social groups to adopt exclusion-based behavioral patterns? The African National Congress, closely cooperating with the Communist Party, was itself a revolutionary movement that postulated a "radical" change after coming to power (Interview with B. Turok, 2019) - so how did it come about that despite formal equality of all citizens the South African habitus is still characterized by such exclusion? Possibly the answer to this question can be found in the analysis of political transition taking place in the Republic of South Africa. Of course, in the context of the discussion of exclusion mechanisms and deepening inequalities in the country, consequences of the racial segregation system are extremely important. Informal apartheid still survives, for example, in the geography of South African cities where inhabitants of rich and poor neighborhoods have no chance to meet in everyday life. In addition, one should also bear in mind the macroeconomic factors enabling the accumulation of wealth discussed among other things by Piketty: capital is concentrated 
in the hands of a small number of people, who will thus be getting richer quicker than others, as gains on capital outweigh gains from other forms of wealth creation. While the author is deeply aware of non-political mechanisms of maintaining and creating exclusion, the present paper focuses on political aspects thereof.

\section{The Mechanism of Maintaining Inequalities as a Consequence of Political Transition}

Many South African intellectuals believed that the speed with which the black elite was able to take over the state was mainly to the credit of the current South African president, Cyril Ramaphosa. As Secretary General of the African National Congress, he has been the ANC's negotiator in its talks with the National Party since 1991. Free elections in South Africa are considered one of the greatest triumphs of democracy in the $20^{\text {th }}$ century. At the same time, one can adopt a different perspective and ask whether the socialization process through the negotiations was entirely unidirectional: did only political groups opposing racial segregation (together with international pressure in that direction) exert influence on the National Party and the South African capitalist elite; or did the proponents of apartheid also socialize the opposition groups they interacted with? The conclusions from conversations with people involved in the processes of apartheid deconstruction all point to one interpretation. The government, along with the economic elite of the time, basically obtained everything they wanted for the price of giving up formal power. It is striking how many heroes of the fight against racial segregation believe that the African National Congress after 1994 (and especially under Thabo Mbeki) betrayed the revolutionary ideals that guided the organization in the 1980s and early 1990s. Lack of action against inequalities and excessive submission of the new political elite to the National Party and the South African and global capitalist elite are criticized by, among others, Ronnie Kasrils (responsible for the intelligence services during the fight against apartheid), Kgalema Motlanthe (former president of the Republic of South Africa) and Ben Turok, co-author of the Freedom Charter - the most important document indicating the goals and methods for combating apartheid adopted by the ANC (Interview with B. Turok, 2019). In the academic sphere, the main critic of ANC's submission to the old political and economic elite was Sampie Terreblanche, author of the most important scientific work on inequality in South Africa (Terreblanche, 2002). In fact, apart from the few members of the government who in any given administration are responsible for coordinating activities under subsequent incarnations of 
the Black Economic Empowerment (BEE) programme or land restitution reform, it is difficult to find any political actors expressing a positive opinion on the state's policies aimed at eliminating inequality.

The fact that apartheid would not survive in the long term was obvious to members of the National Party already in the late 1980s (Beinart, 2001, pp. 314-315); the most important question was rather what would be the conditions of the looming political transition. The political sphere - together with the performative dimension of the CODESA (Convention for a Democratic South Africa) and MPNF (Multiparty Negotiating Forum) negotiations - counterparts of the Polish round table - together with involvement of international politicians (including Henry Kissinger or Lord Carrington), the Nobel Peace Prize for Nelson Mandela and Frederik de Klerk, peaceful elections in 1994, and finally the worldwide broadcast of Mandela being sworn in as President in the absence of opposition and even salutes for the first black president from the white-dominated armed forces - all supported the narrative of systemic transformation undertaken in the best interest of "all" South African people. However, the new black political elite was largely assimilated into the old elites, and principles of their cooperation and mutual relations were institutionalized during the presidency of Nelson Mandela. Next, the period of Thabo Mbeki's rule marked a complete departure from the revolutionary ideals of the African National Congress in the economic sphere. Yoichi Mine believes that the principle of governmental non-interference into right to property and attachment to the principles of market economy - characteristic of the administration of Nelson Mandela's successor in the presidential office ensured that the white minority active in the state's economy not only refrained from criticism of the ANC, but even supported the party in some cases (Mine, 2013, p. 109). Assimilation of the new political elite into the forces of old can be demonstrated by the fact that the direct successor of the National Party, the New National Party, has been formally incorporated into the African National Congress only 10 years after the first free elections.

Many commentators of the South African political arena point to informal negotiations between decision-makers in the ANC and representatives of the South African financial elite that started after the release of Nelson Mandela. Mandela himself often met with Harry Oppenheimer, while the ANC leaders spoke to key South African entrepreneurs. This led to black politicians, in the end, holding shares in the largest companies from the minerals-energy complex, the backbone of the South African economy (Southall, 2012). The beneficiary of this process is, inter alia, the current president of South Africa Cyril Ramaphosa, who is perceived by the current political and financial elite as a guarantor of non-implementation 
of revolutionary provisions of the Freedom Charter. Key eneablers of the process of very rapid enrichment of selected black South African citizens are rooted in the process of political transformation, and its unexpected consequence are the deepening social divisions and the slow collapse of some of the state-owned enterprises.

The best illustration of how the creation of a new political elite looked like in practice is the direct account of Ben Turok. According to the sunset clauses proposed by the Communist Party leader Joe Slovo in 1992, parties that would cross the $10 \%$ threshold in elections had guaranteed participation in the newly constituted government. Additionally, civil servants nominated by the National Party would not lose their jobs or privileges associated with it for the coming 10 years. Of course, the African National Congress needed specialists and technocrats to manage the country. The Republic of South Africa in mid-1990s was a middle-income country with a diversified economy. To put it simply, the ANC did not have at its disposal staff capable of replacing civil servants associated with the National Party. Ben Turok recalls that the ANC had people educated at Bantustan universities - and explains that education at such a university was worth less than nothing (Interview with B. Turok, 2019). According to his account, during talks on the form of cooperation between the ANC and the National Party after the 1994 election, the dominant theme was what cars the government members would be provided with, not how to implement policies that would reduce social inequality. Undoubtedly, the sunset clauses ensured political stability, but their unexpected (as evidenced by conversations with participants of the transformation process) consequence was the need to offer the new members of state administration the same privileges as those enjoyed by the administration under apartheid. One could not, after all, treat black officials worse than their white predecessors who kept their privileges... Assuming that any bureaucratic structure has its memory and desire to survive, maintaining privileges from the period of racial segregation meant that the new system would also be built on exclusivity and exploitation. Constructivist approaches focus on mutual learning processes in which identities, interests and values are shaped. It is worth considering which party really took on the role of educator after 1994, and whether identities of institutions operating in the state were not resistant and durable enough to socialize new members of the administration to adopt specific, surviving behavioral patterns built on exclusion. It cannot be logically expected that the South African state would care for equal opportunity creation in the economy for all citizens, even if actions postulated by the ANC pre1992 and aimed at the redistribution of the means of production have not been implemented. If the material status of the previous financial elite was maintained, and the members of the state administration did not lose their privileges, where 
could the black South African residents find the social and economic capital needed to bolster them and enable them to compete with the previous economic elite in different arenas? Hypothetically, one could hope for communist countries to offer external help in the form of financial resources and technical knowledge and know-how for the new Republic of South Africa. However, with the dissolution of the Eastern Bloc and the collapse experienced by Russia under Boris Yeltsin, it was certain that none of the former people's democracies would provide financial support to South Africa at the time. In fact, the world of the early 1990s seemed to accept Francis Fukuyama's thesis that the most effective governance model in the economic and political sphere is the democratic system with a free market economy. The macroeconomic realities of South Africa in 1994 were such that the budget deficit at the end of the National Party rule exceeded 8\% of GDP and a loan from the International Monetary Fund (IMF) was necessary to balance the budget. The IMF at the time was dominated by supporters of economic neoliberalism. Despite international support for the transformation processes in South Africa, it was unlikely that the IMF would extend a loan to an administration planning a radical change in ownership structures in the state, particularly one involving nationalization of the extractive industries, agricultural land reform and takeover of the banking sector by the state (Terreblanche, 2018).

According to Ben Turok, maintenance of preexisting privileges of civil servants and adoption by new members of the administration of habits created during the apartheid period were behind the lack of more decisive actions aimed at equalizing the injustices of apartheid. The new elite was socialized by the old one, and largely dependent on expert knowledge of the former. Many South African companies were huge enterprises (e.g., ESCOM, the electricity utility, was the fifth-largest enterprise of its type in the world) which were supposed to operate (at least according to rhetorics) for the benefit of all South African people. There could be no question of their takeover by the state. At the same time, despite the ANC's resignation from the plan of forced agricultural land reform and state takeover of the mining industry, the Mandela administration did commence implementation of the so-called Reconstruction and Development Programme (RDP), the main element of which was the development of broadly understood infrastructure (access to water, housing, schools and medical care) in locations excluded from development processes during the apartheid period. Simultaneously, the economic elite was on a voluntary basis implementing the Black Economic Empowerment programme (BEE). It consisted of granting selected black South African residents shares and places on boards/in supervisory bodies of companies previously managed by whites. Over a very short period, a group of very rich black businessmen emerged. 
The appearance of black citizens on supervisory and management boards of large South African corporations was in line with social expectations; it could even be considered as a form of a social safety valve as people saw visible changes taking place: black people were suddenly on the lists of richest South Africans. The "product" of this change was, inter alia, the current President of South Africa Cyril Ramaphosa. The business elite was well aware that it had to grant access to economic capital to the (selected) black elite, as maintaining wealth only in the hands of whites would likely put the issues of restitution and ownership transformation back on the table as real topics of public discussion. In addition, it was an open secret that uncompelled handover of some shares in businesses by the white financial elite was seen as an "additional tax" whose voluntary adoption meant that the issue of taxation on wealth was not raised at all in the public debate (Interview with A. Donaldson, 2019). In the period of political transformation, black activists possessed only political capital - this capital, however, was necessary to sanction the lack of changes in ownership structure which in turn allowed for continued capital accumulation by the old financial elite. An extremely important moment in this process was the ascent to power of Thabo Mbeki, whose administration officially abandoned the aforementioned Reconstruction and Development Programme in favor of the neoliberal programme named Growth, Employment and Redistribution (GEAR) (Jordan, 2004, p. 210), in which achievement of economic success by citizens was left largely to market forces. This failure to implement the postulates of land restitution or nationalization of the mining and financial sectors is the foundation of support offered by South African business circles to the ANC after Nelson Mandela handed over the power (Mine, 2013, p. 109). The "redistributive" element in the GEAR programme had nothing to do with the acquisition of property, and in practice boiled down to direct money transfers in the form of social grants to the poorest inhabitants of South Africa. Growing population of the Republic and gradual expansion of the range of benefits have led to 17 million South Africans being now fully dependent on welfare transfers received from the ANC-dominated government.

The symbiotic relationship between business and politics developed during the transition and consolidated during Thabo Mbeki's rule degenerated into a form focused on maximizing individual interests during the presidency of Jacob Zuma, which culminated in the so-called state capture scandal (Shai, 2017). The investigation, ongoing as I am writing this paper, reveals how pathological the relations between business and state administration were in this case - but conditions for the development of this "new type of corruption" had been created before Jacob Zuma took the presidential office. It remains nonetheless true that under Zuma, 
draining of state resources to achieve private goals was taking place simultaneously with lack of any action aimed at changing the ownership structure of South African economic capital. This in practice strengthened structures preventing the majority of society from accumulating capital.

\section{Final Conclusions}

The main conclusion of the study is that relations established throughout the time of negotiations on the deconstruction of the apartheid system and their later perpetuation - observed for example in the ANC rejecting the call for radical changes in the ownership structures - led to further social stratification. Research into inequalities places a burden of moral responsibility onto its authors, along with mental discomfort. The fact that the majority of the South African population lives in relative poverty combined with the structural impossibility of changing this state of affairs through wealth accumulation makes this country a great location to research inequalities. Author's focus on inequalities during his research means that to some degree he is making money due to the poverty and precarity suffered by most of the South African citizens. The present paper was primarily intended to showcase the processes that led to deepening of inequalities in the Republic of South Africa - at the same time, because of the nature and subject of the study, the author feels morally compelled to at least synthetically sketch out actions that should or should not be taken to change this situation.

As mentioned above, apart from the political circumstances that prevented the implementation of the ANC's drastic reform plans focused on redistribution of the means of production, every study on inequalities in South Africa requires giving due consideration to the consequences of apartheid. Probably the most visible of them is the concentration of wealth in a limited number of locations: the largest number of millionaires live in Johannesburg, though in the Western Cape Province within the boundaries of the regions of Paarl (120,000 inhabitants), Franschhoek (17,000 inhabitants) and Stellenbosch (19,000 inhabitants) live another 3,200 dollar millionaires (de Villiers, 2018; AfrAsia Bank, 2019) For comparison, according to the Wprost ranking of "zloty millionaires" - 3,400 of them live in the capital city of Warsaw itself, while, for example, the entire Dolnośląskie Voivodeship can boast "only" 1,200 (Wprost, 2018). Such clustering of the wealthiest within a small number of communities in South Africa makes the differences in the standard of living very explicit and eye-catching. This high concentration of capital and relative openness of the South African economy have 
its consequences - simply put, the capital can very easily be transferred to another place, another country included, which is why any radical government action (such as nationalization) would likely lead only to a blackmail: the economic elites would make use of the threat of moving outside the borders of South Africa. The bad macroeconomic situation of the state also makes it difficult for the Republic to attract foreign investment. A well-reasoned step for South Africa in its current condition seems to be the introduction of a wealth tax. This postulate, however, gives rise to the technical problem of having to assess the wealth of South African people before taxing it, which seems an extremely difficult task - though it is not entirely impossible. A second, more idealistic postulate would be the formation of a coalition government ${ }^{5}$, in which another political grouping would be able to balance out the African National Congress, the party that has been ruling the country for a quarter-century now. The worst of possible scenarios would be revolutionary changes, of the type postulated, inter alia, by the Economic Freedom Fighters. Correlations between the situation in South Africa and that of Zimbabwe seem obvious. The transfer by Robert Mugabe of land owned previously by white farmers into the hands of members of the ruling party with no knowledge of industrial-scale agriculture was a key contributor to the deepening recession in Zimbabwe. In the context of South Africa, the land has a symbolic significance and, taking into account the contribution of agriculture to the state GDP, it is unlikely that a land reform following the model implemented in Zimbabwe would aid in minimizing inequalities in the Republic of South Africa.

\section{References:}

AfrAsia Bank (2019). The 2019 South Africa Wealth Report Describes Growth at Home as Moderate. Retrieved from: https://www.afrasiabank.com/en/about/newsroom/news/ 2019/the-2019-south-africa-wealth-report-describes-growth-at-home-as-moderate. Beinart, W. (2001). Twentieth Century South Africa. Oxford: Oxford University Press. Electoral Commission of South Africa (n.d.). Retrieved from: https://www.elections.org.za. Hanoman, J. (2018). Hunger and Poverty in South Africa: The Hidden Faces of Food Insecurity. New York: Routledge.

Hirsch, A. (2005). Season of Hope: Economic Reform Under Mandela and Mbeki. Pietermaritzburg: University of KwaZulu-Natal Press.

${ }^{5}$ Formally, the ANC governed jointly with the South African Communist Party and COSATU, the Congress $\mathrm{f}$ South African Trade Unions - it was clear though that the ANC had an uncontested dominant position in this tri-party coalition. 
Interview with Andrew Donaldson (2019, February 20). Deputy Director-General in the National Treasury, Cape Town.

Interview with Ben Turok (2019, February 20). Institute for African Alternatives, Cape Town.

Interview with Jeremy Seekings (2019, February 19). University of Cape Town, Department of Sociology.

Jerven, M. (2013). Poor Numbers: How We Are Misled by African Development Statistics and What to Do About It. Ithaca and London: Cornell University Press.

Jordan, P. (2004). The African National Congress: From Illegality to the Corridors of Power. Review of African Political Economy, 31(100), 203-212. DOI: 10.1080/03056 24042000262248.

Milanovic, B. (2016). Global Inequality: A New Approach for the Age of Globalization. Cambridge: Harvard University Press.

Mine, Y. (2013). Beyond Ad hoc Power-Sharing: Comparing South Africa and Zimbabwe. In: Y. Mine, F. Stewart, S. Fukuda-Parr, \& T. Mkandawire (eds.). Preventing Violent Conflict in Africa: Inequalities, Perceptions and Institutions (pp. 95-125). New York: Palgrave Macmillan.

Neubert, D. (2019). Inequality, Socio-cultural Differentiation and Social Structures in Africa: Beyond Class. New York: Palgrave Macmillan.

Oxfam (2019). Public Good or Private Wealth? Retrieved from: https://oxfamilibrary.openrepository.com/bitstream/handle/10546/620599/bp-public-good-or-private-wealth210119-en.pdf.

Piketty, T. (2015). Kapitat w XXI wieku. Warszawa: Wydawnictwo Krytyki Politycznej.

Polus, A., \& Cześnik, M. (2016). Reforma rolna w Zachodniej Prowincji Przylądkowej Republiki Południowej Afryki. Politeja, 13(43), 121-138. Retrieved from: http://akademicka.pl/ebooks/free/a80897cfaa6b1c7d5a1593c0c3a0ff3e.pdf. DOI: 10.12797/Politeja.13.2016.43.05.

Shai, K.B. (2017). South African State Capture: A Symbiotic Affair between Business and State Going Bad(?) Insight on Africa, 9(1), 62-75. DOI: 10.1177/0975087816674584.

Southall, R. (2012). South Africa's Fractured Power Elite. Seminar at Witwatersrand University, 1-17. Retrieved from: https://wiser.wits.ac.za/system/files/seminar/Southall20 12_0.pdf.

Statistics South Africa (2017). Poverty Trends in South Africa: An Examination of Absolute Poverty between 2006 \& 2015. Retrieved from: https://www.statssa.gov.za/?p=10341.

Statistics South Africa (n.d.). Retrieved from: http://www.statssa.gov.za/?cat=22.

Terreblanche, S. (2002). A History of Inequality in South Africa, 1652-2002. Pietermaritzburg: University of KwaZulu-Natal Press.

Terreblanche, S. (2018, January 25). The Co-optation of the African National Congress: South Africa's Original 'State Capture'. Pambazuka News. Retrieved from: https://www. sahistory.org.za/article/co-optation-african-national-congress-south-africas-originalstate-capture-sampie.

The Economist (2016, April 2). Globalisation and Inequality. The New Wave. The Economist. Retrieved from: https:/www.economist.com/books-and-arts/2016/04/02/thenew-wave. 
Therborn, G. (2019). South African Inequalities in a Global Perspective. In: C. Soudien, V. Reddy, \& I. Woolard (eds.). Poverty \& Inequality: Diagnosis, Prognosis, Response (pp. 31-41). Braamfontein: HSRC Press.

de Villiers, J. (2018, April 5). There are Now 3,200 Dollar Millionaires Living in Paarl, Franschhoek and Stellenbosch. Business Insider SA. Retrieved from: https://www.businessinsider.co.za/paarl-franschhoek-stellenbosch-are-the-fastest-growing-south-african-areas-of-dollar-millionaires-2018-4.

Wprost (2018, July 16). Przybywa milionerów. Najwięcej jest ich w Warszawie. Wprost. Retrieved from: https:/www.wprost.pl/kraj/10139757/przybywa-milionerow-najwiecej-jest-ich-w-warszawie.html. 